Kolozsvár, 1998. március 20-21.

\title{
Összefüggés a sokszögprofilok felületi érdesség - görbületei között
}

\author{
Dr. Jakab Endre, Dr. Tajnafői József, Gombos Rita Kornélia
}

\begin{abstract}
ion
The flexibile grinding-tools can be used for different processes in variation ways. I studied the so processed an epihcyclois teeth cylindrical wheel and Type P3G polygon shaft. I have done a study on the roughness fo assembly pieces having been formed by band-ginding. I made the measurements with a SURTRONIC 3++ surface roughness measuring applience. I determined the relations between surface roughness values and radius of curvature of circular polygon porfiles.
\end{abstract}

\section{Feladat}

A [1] cikkben bemutattuk azokat a vizsgálatokat, amelyek alapján a sokszögprofilok felületi érdességének változására tudtunk következtetéséket levonni. Folytatva a gondolatot célul tüztük ki a vizsgált profilok mért keresztmetszeteiben a görbületek, illetve görbületi sugarak meghatározását és a felületi érdességek változásának bemutatását ennek függvényében, ami az azonos profiloldalak szemléletesebb összehasonlítására is módot ad. Ezen cikk keretében a P3G típusú poligon tengelyre vonatkozó vizsgálatok eredményeit ismertetjük részletesen.

\section{A poligon profil görbületei és görbületi sugarai}

A geometriai származtatás alapján felírható, a derékszögü koordinátákra vonatkozó skaláris egyenletek:

$$
\begin{aligned}
& \mathrm{x}=\frac{\mathrm{D}_{\mathrm{m}}}{2} \cos \alpha-\mathrm{e} \cos \alpha \cos \mathrm{N} \alpha-\mathrm{Ne} \sin \alpha \sin \mathrm{N} \alpha \\
& \mathrm{y}=\frac{\mathrm{D}_{\mathrm{m}}}{2} \sin \alpha-\mathrm{e} \sin \alpha \cos \mathrm{N} \alpha+\mathrm{Ne} \cos \alpha \sin \mathrm{N} \alpha
\end{aligned}
$$


A görbületi sugarakra vonatkozó összefüggés:

$$
\rho=\frac{1}{K}=\frac{\left|2 \mathrm{e}\left(\mathrm{N}^{2}-1\right) \cos \mathrm{N} \alpha+\mathrm{D}_{\mathrm{m}}\right|}{2}
$$

\section{Kísérleti megmunkálások, felületi érdességek mérése}

A megmunkálásokra és a felületi érdesség mérésekre vonatkozó részletes ismertetést a [2] irodalom tartalmazza. Az 1. és a 2. ábrák a megmunkált alkatrészeket és a mérési helyeket mutatják.

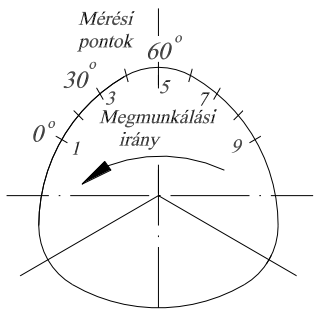

1. ábra

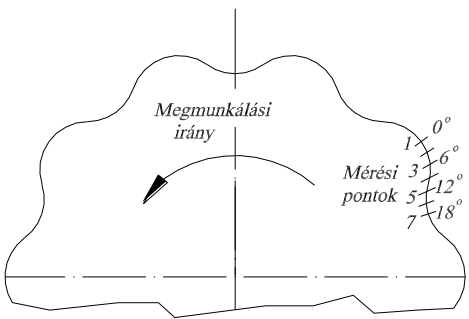

2. ábra

P3G típusú poligon tengely profilja

\section{Mérési eredmények}

A számított görbületi sugarak és a mért felületi érdesség paraméterek közötti összefüggéseket táblázat, másrészt diagramok mutatják.

\begin{tabular}{|c|c|c|c|c|c|}
\hline$\alpha\left(^{\circ}\right)$ & 0 & 15 & 30 & 45 & 60 \\
\hline$\rho(\mathrm{mm})$ & 33.35 & 29.83 & 21.35 & 12.86 & 9.35 \\
\hline Mérési pontok & 1 és 9 & 2 és 8 & 3 és 7 & 4 és 6 & 5 \\
\hline
\end{tabular}

1. táblázat

A P3G típusú poligon tengely görbületi sugarai 


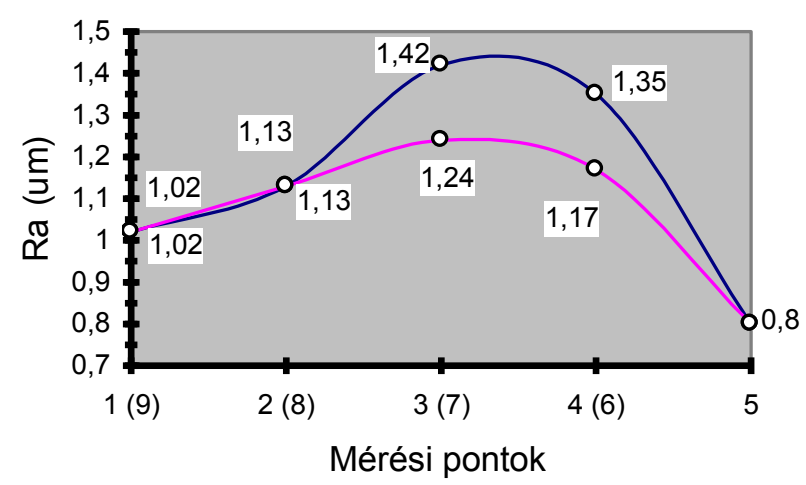

3. ábra

P3G típusú poligon tengely Ra felületi érdesség viszonyai

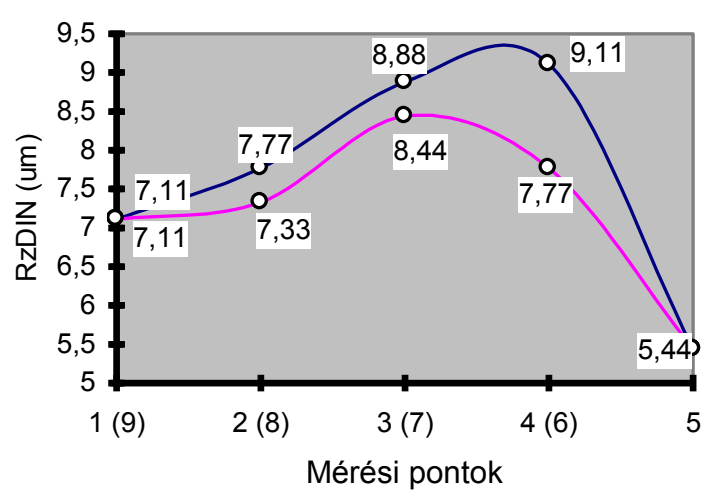

4. ábra

P3G típusú poligon tengely RzDIN felületi érdesség viszonyai

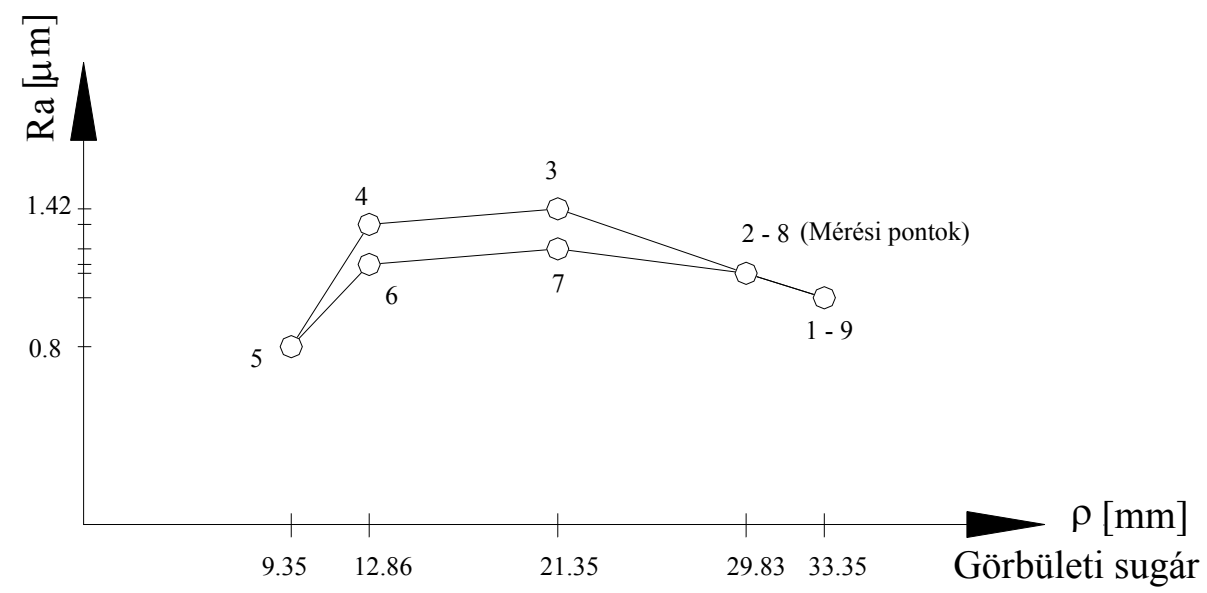

5. ábra

P3G típusú poligon tengely felületi érdességének változása a görbületi sugár függvényében

\section{Mérési eredmények kiértékelése}

- a legkisebb felületi érdesség paraméterek a csúcsokon illetve a tengelyeknél a lapközepeken adódtak, amikor a munkadarab és a szalagköszörü kontakt görgő középvonalára fektetett sík vízszintes,

- a legnagyobb felületi érdesség paraméterek az epiciklois fogazatú keréknél a fogazatok inflexiós pontja környezetében, a P3G poligon tengelyeknél a lapközép és a csúcs középtáján adódtak,

- azonos görbületi sugarú helyeken eltérő felületi érdesség paraméterek adódtak, a vizsgált profil két szimmetrikus ágán, a kapcsolódási pont vándorlása, illetve a munkadarab-szerszám közötti relatív sebesség eltérése miatt; az epiciklois fogazatoknál az 1-7. mérési pontok 
között (fogároktól fogtetőig) a felületi érdesség paraméterek nagyobbak, mint a fogtető és a fogárok (7-13. mérési pontok) közöttiek; a poligon profilok esetén a lapközép és a csúcs (1-5. mérési pont) közötti felületi érdesség paraméterek nagyobbak, mint a csúcs és a lapközép (59. mérési pont) közöttiek,

- a P3G profilnál és az epiciklois fogazatoknál a szimmetrikus két oldalon mért felületi érdességek értéke akár 15-25\%-al is különbözhet egymástól.

\section{Jövőbeni célkitűzések}

- kapcsolódási pont vándorlás-relatív sebességek és az érdességek kapcsolatának, valamint a profilmenti érdesség-változásnak a szerkezet müködését befolyásoló hatásának vizsgálata,

- jellegzetes alkatrész leírás és megmunkálási feladatainak megoldása,

- szalagköszörü gépen megmunkált alkatrészek a méret-, alakpontosságára valamint a felületi minőségre vonatkozó mérések,

- szerszámok megválasztása, optimális forgácsolási paraméterek beállítása kísérletekkel.

\section{Irodalomjegyzés}

[1] GOMBOS,R.: Sokszögprofilok felületi érdesség változásának vizsgálata. Dokturanduszi konferencia, Miskolc. 1997.

[2] GOMBOS,R.: Epiciklois és poligon profilok érdesség vizsgálata. Tudományos

Diákköri

Dolgozat, Miskolc, ME Szerszámgépek Tanszék, 1997.

Gombos Rita Kornélia / Ph.D hallgató

Miskolci Egyetem, Szerszámgépek Tanszéke / 3515 Miskolc-Egyetemváros

06-46-365-111(19-12) 